\title{
AGE PECULIARITIES OF KNEE FUNCTIONALITY AND PHYSICAL PERFORMANCE IN ELDERLY WOMEN
}

\author{
R.O. Solodilov, goodroman@mail.ru, ORCID: 0000-0002-4837-7427 \\ Surgut State University, Surgut, Russian Federation
}

\begin{abstract}
Aim. The aim of this study is to learn the effect of the age on degenerative knee joint disease and physical capability of elderly women. Materials and methods. Three groups of relatively healthy elderly women $(\mathrm{G} 1-60-64$ years $(\mathrm{n}=34), \mathrm{G} 2-65-69$ years $(\mathrm{n}=31)$ and G3 $70-74$ years $(\mathrm{n}=18))$ participated in the study. The functional status of the knee joint (pain, limitation of motion, physical functionality) was estimated with the help of WOMAC index. Physical performance in women was studied with the help of three functional tests. Pain in the knee joint before and after the tests was assessed with the help of the Numeric Pain Rating Scale (NPRS). Statistical data were processed with the help of Statistica 10 and IBM SPSS22. Results. Pain and stiffness in the knee joint in elderly women increased significantly with age while physical functionality decreased $(\mathrm{p}<0.01)$. Correlations were established between "age/pain" $-(\mathrm{r}=0.581)$, "age/stiffness" - $(\mathrm{r}=0.565)$ and "age/physical functionality" - $(\mathrm{r}=0.666)$ indices, $\mathrm{p}<0.01$. Authentic changes of the pain index were revealed in the knee joint during physical activity. Correlation analysis showed a clearly defined dependence between the level of physical capability in women and their age. Conclusion. The data obtained prove that the age of elderly women is one of the main factors influencing their functional capability. The age also is one of the factors influencing the progression of functional and degenerative disorders in the knee joint.
\end{abstract}

Keywords: elderly women, knee joint, physical capability, WOMAC.

Introduction. Functional disorders of the knee joint have major influence on the level of physical activity and working capability of elderly people [14]. The functional integrity of the knee joint and its structural elements influences not only physical capability and physical activity but also the quality of human life on the whole. One of the main factors of well-being of elderly people is the capability to lead a healthy life. The majority of experts share the view that the main component of such a life is maintaining the optimal level of physical activity in all forms of its expression $[8,11]$. The capability of a person to maintain the necessary level of functional independence is becoming lower with age, essential blood supply and oxygenation of skeletal muscles decrease, the strength and the speed of their contraction decrease [2], brittleness of the bones increases, joint mobility increases leading to the change of a rational stereotype of limb movement on the whole. Thus, there are changes of a movement stereotype, which affect physical qualities and recovery of complex movements [7].

Interest to the question of maintaining physical activity is affirmed by the results of many studies conducted in Russia [10] and abroad [1]. It is known that elderly people spend up to $86 \%$ of their time sitting, and about $57 \%$ of elderly people cannot return to the previous level of physical activity [9]. Functional and degenerative disorders of the knee joint concern up to $10 \%$ of people over 60 years old [4]. Women are more in danger of functional and degenerative disorders in the knee joints than men [6], especially in extreme conditions of the Russian north [5]. The functional correction of the locomotion system in elderly people is a complicated and multifaceted problem, which cannot be solved without searching the functional features of its separate elements, especially against the increase in the number of elderly people [16] and their incapacitation [13].

Materials and methods. Relatively healthy elderly women aged from 60 to 74 years participated in the study. All participants were selected according to the inclusion and exclusion criteria (Table 1).

Using these criteria, we divided the participants into three research groups: group 1 60-64 years $(\mathrm{n}=34)$, group $2-65-69$ years $(\mathrm{n}=31)$ and group $3-70-74$ years $(\mathrm{n}=18)$ (Table 2). All participants $(\mathrm{n}=83)$ did not have contraindications to the exercise stress at the moment of the research and gave voluntary written informed consent approved by the Ethics Committee of the Surgut State University. 
Inclusion and exclusion criteria

\begin{tabular}{|c|c|}
\hline Inclusion Criteria & Exclusion Criteria \\
\hline $\begin{array}{l}\text { 1. Age: } 60-74 \text { years. } \\
\text { 2. Capability of moving without using assistive devices. } \\
\text { 3. Capability of standing up from a chair for no less } \\
\text { than } 5 \text { times without using hands }\end{array}$ & $\begin{array}{l}\text { 1. Neurological conditions or diseases of the locomotor } \\
\text { system, which can influence the results of the research. } \\
\text { 2. Diseases of the extensor mechanism of the knee. } \\
\text { 3. Anesthetic apparatus and/or injections }\end{array}$ \\
\hline
\end{tabular}

Characteristics of the sample $(\mathrm{M} \pm \sigma)$

Table 2

\begin{tabular}{|l|c|c|c|}
\hline \multicolumn{1}{|c|}{ Characteristic } & Group 1, $\mathrm{n}=34$ & Group 2, $\mathrm{n}=31$ & Group 3, $\mathrm{n}=18$ \\
\hline Age, years & $60-64$ & $65-69$ & $70-74$ \\
\hline Average age, years & $62,1 \pm 1,4$ & $66,3 \pm 1,2$ & $71,7 \pm 1,3$ \\
\hline Body length, cm & $166,4 \pm 1,7$ & $165,3 \pm 1,4$ & $163,5 \pm 1,3$ \\
\hline Body mass, $\mathrm{kg}$ & $63,7 \pm 1,5$ & $69,1 \pm 1,7$ & $68,2 \pm 1,7$ \\
\hline Body Mass Index, $\mathrm{kg} / \mathrm{m}^{2}$ & $23,1 \pm 0,2$ & $25,8 \pm 0,3$ & $25,6 \pm 0,3$ \\
\hline
\end{tabular}

The functional status of the knee joint was assessed using WOMAC index [15] (Nicholas Bellamy, Queensland, Australia). This index contains 24 criteria, which are divided into 3 subscales - joint pain ( 5 criteria), stiffness ( 2 criteria) and physical function (17 criteria). Low values of the criteria characterize a lower intensity of pain and stiffness in the joint during exercise and a higher level of functional performance.

Three physical performance tests were conducted, the timed up and go test (TUG), the 6minute walk (6MW) and sit to stand test (STS). The TUG identifies the level of functional mobility and is considered as reliable and valid in community-dwelling older adults. It is a timed measure of a person's ability to stand from a chair, walk three meters, turn 180 degrees, return to the chair and sit down. The $6 \mathrm{MW}$ defines the capability of a person to move independently when during a definite time it is necessary to walk at the greatest possible distance. The STS test requires the participant to stand up from the chair, the height of which is regulated at the level of $110 \%$ from knee height, with hands crossed at the level of the chest. Before and after the tests the intensity of knee joint pain was measured. Pain was estimated with the help of Numeric Pain Rating Scale (NPRS) with a 10-point scale, where $10=$ exquisite pain, $0=$ no pain. The participants of the research were asked to choose a number on the scale to describe the intensity of pain feeling at the moment.

Statistical analysis was performed using Statistica 10 (StatSoft Ink, USA) and IBM SPSS 22 (IBM, USA). The normality of distribution was tested by the Shapiro-Wilk and KolmogorovSmirnov tests. To estimate the confidence level between groups, we used the Wilcoxon signedrank test. Independent samples t-tests were used to analyze differences between groups for the TUG, 6MW and STS tests. The level of statistical significance was established at $\mathrm{p}<0.05$.

Results. Table 3 shows the results of analysis on the effect of age on the functional indices of the knee joint in elderly women.

It was established that pain and stiffness in the knee joint in elderly women increased significantly with age while physical functionality

Knee pain, stiffness, and physical function, WOMAC score in $\mathrm{mm}(\mathrm{M}, 95 \% \mathrm{Cl})$

Table 3

\begin{tabular}{|l|c|c|c|c|c|c|}
\hline \multicolumn{1}{|c|}{ Criterion* } & $\mathrm{G} 1, \mathrm{n}=34$ & $\begin{array}{c}\mathrm{p} \\
\mathrm{G} 1-\mathrm{G} 2\end{array}$ & $\mathrm{G} 2, \mathrm{n}=31$ & $\begin{array}{c}\mathrm{p} \\
\mathrm{G} 2-\mathrm{G} 3\end{array}$ & $\mathrm{G} 3, \mathrm{n}=18$ & $\begin{array}{c}\mathrm{p} \\
\mathrm{G} 1-\mathrm{G} 3\end{array}$ \\
\hline $\begin{array}{l}\text { WOMAC, } \\
\text { pain }\end{array}$ & $\begin{array}{c}8,1 \\
(7,1 ; 9,1)\end{array}$ & 0,0010 & $\begin{array}{c}11,2 \\
(9,7 ; 12,6)\end{array}$ & 0,0011 & $\begin{array}{c}16,4 \\
(13,2 ; 19,7)\end{array}$ & 0,0000 \\
\hline WOMAC, stiffness & $\begin{array}{c}6,1 \\
(4,9 ; 7,1)\end{array}$ & 0,0833 & $\begin{array}{c}7,2 \\
(6,4 ; 8,0)\end{array}$ & 0,0001 & $\begin{array}{c}10,4 \\
(8,8 ; 12,1)\end{array}$ & 0,0000 \\
\hline $\begin{array}{l}\text { WOMAC, physical } \\
\text { function }\end{array}$ & $\begin{array}{c}51,2 \\
(45,5 ; 56,9)\end{array}$ & 0,0000 & $\begin{array}{c}83,8 \\
(79,4 ; 88,3)\end{array}$ & 0,9940 & $\begin{array}{c}84,2 \\
(72,5 ; 95,2)\end{array}$ & 0,0000 \\
\hline
\end{tabular}

Note. * - WOMAC pain subscale, possible score 0-500 mm; WOMAC stiffness subscale, possible score 0-200 mm; WOMAC physical function subscale, possible score 0-1700 mm. 
decreased $(\mathrm{p}<0.01)$. Most often correlation is established between the age and physical function subscale $(r=0.666 ; p<0.01)$ (Fig. 1).

Correlation between age-pain (Fig. 2) and age-stiffness (Fig. 3) indices had a less pronounced character of $r=0.581$ and $r=0.565$ respectively $(\mathrm{p}<0.01)$. However, the dependence of these characteristics shows an essential influence of age on the functional condition of the knee in elderly women. The data obtained provide a strong evidence that the age of elderly women is one of the main factors influencing the progression of functional disorders in the knee joint.

Physical function, score vs. Age, years Age, years $=57,813+, 11308$ * Physical function Correlation: $\mathrm{r}=, 66649$

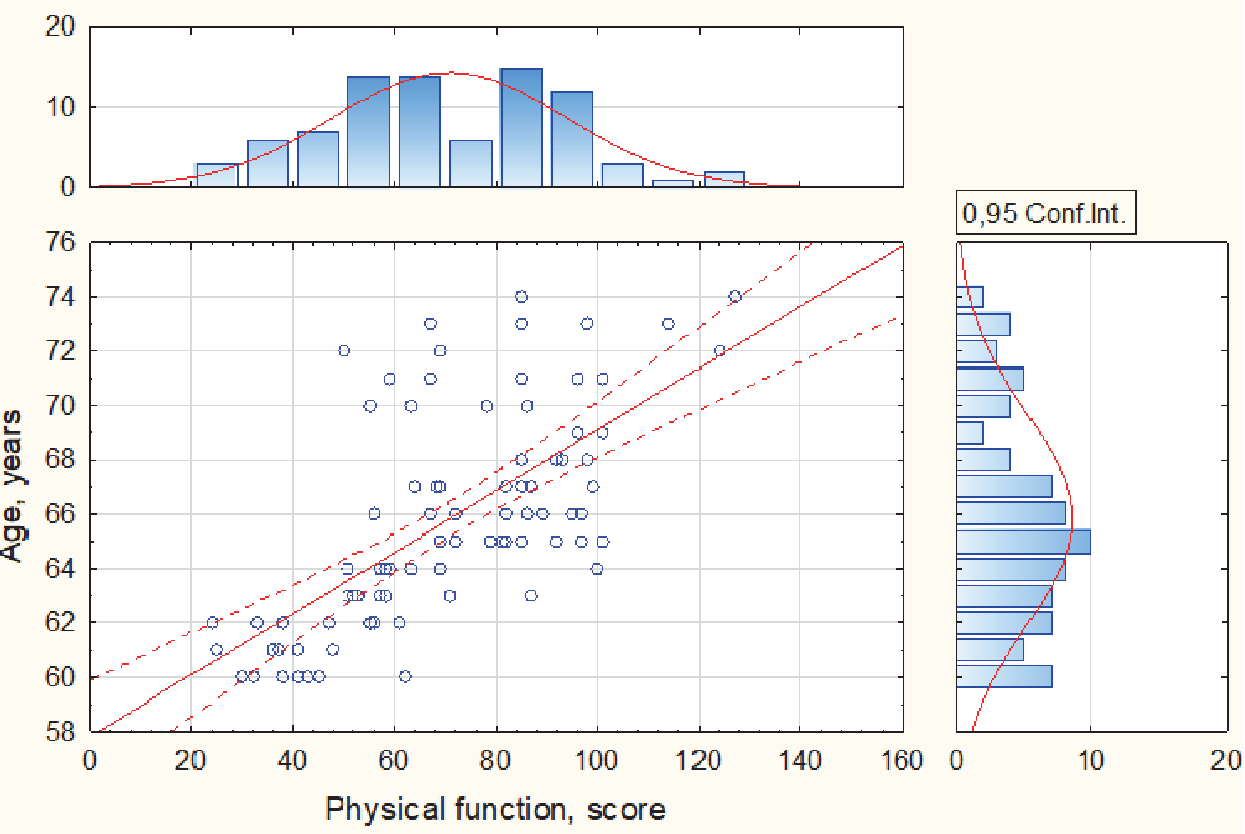

Fig. 1. Correlation between the age and physical functional subscale (M, 95\% $\mathrm{Cl}$ )

Age, years $=61,062+, 42590{ }^{*}$ Pain

Correlation: $r=, 58104$
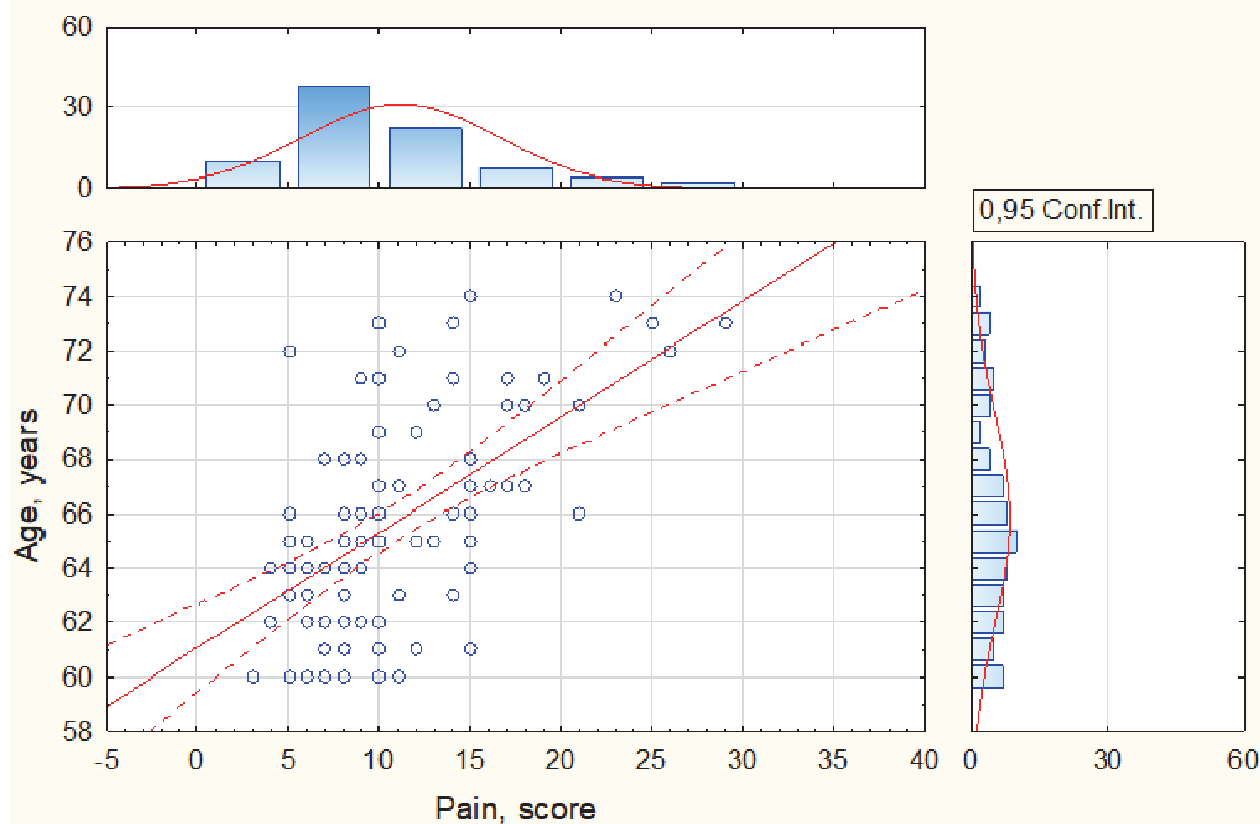

Fig. 2. Correlation between the age and pain subscale, (M, 95\% Cl) 


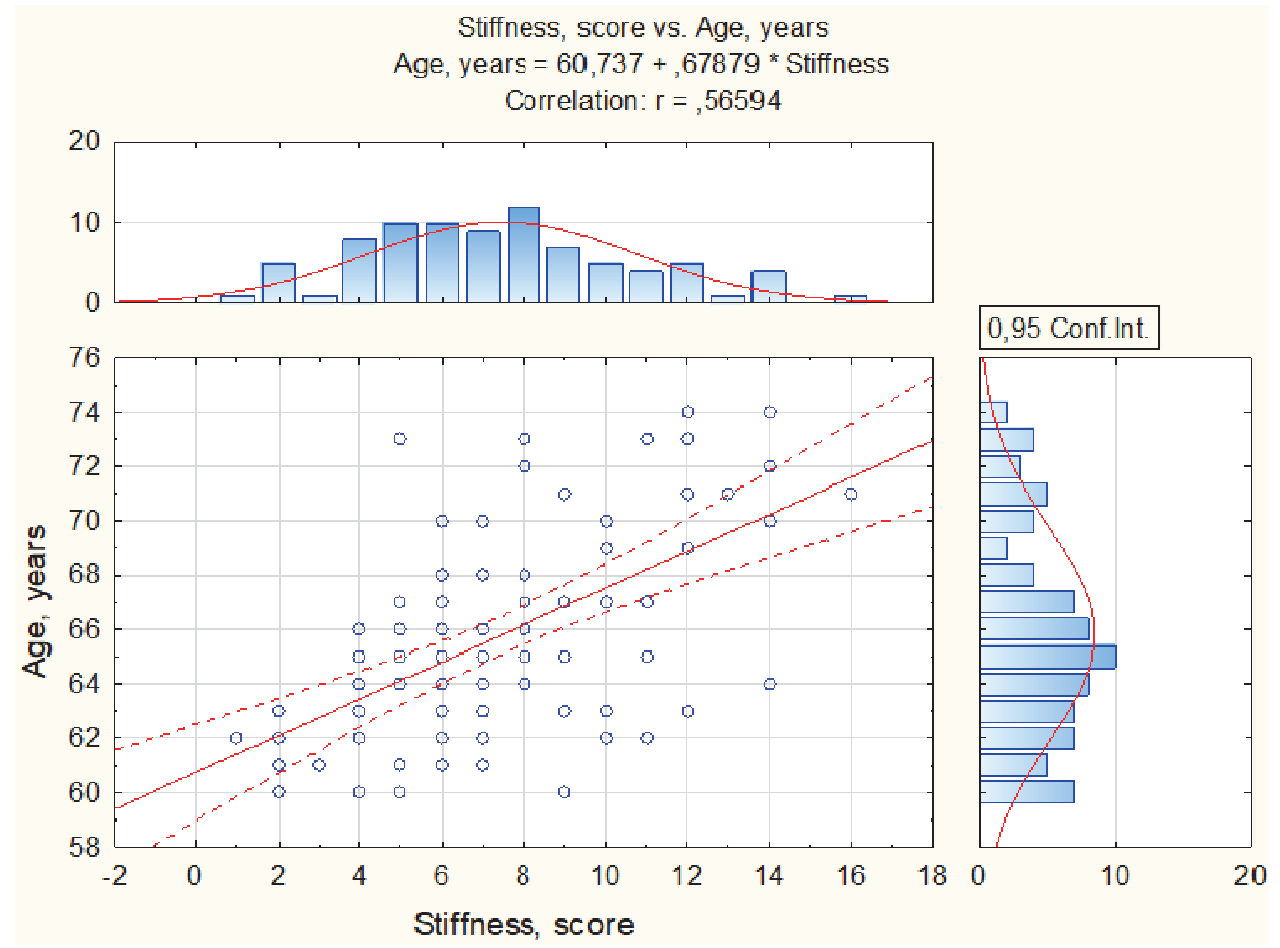

Fig. 3. Correlation between the age and stiffness subscale $(\mathrm{M}, 95 \% \mathrm{Cl})$

Knee pain severity, pretest-posttest change, Numeric Pain Rating Scale (NPRS), points (M, 95\% Cl)

\begin{tabular}{|c|c|c|c|c|}
\hline Measure & $\begin{array}{c}\text { Knee Pain Severity, } \\
\text { M, 95\% CI }\end{array}$ & $\mathrm{p}$ & $\begin{array}{l}\text { Minimum pain } \\
\text { for the last } 24 \text { hours }\end{array}$ & $\begin{array}{l}\text { Maximum pain } \\
\text { for the last } 24 \text { hours }\end{array}$ \\
\hline \multicolumn{5}{|c|}{ Group 1: $60-64$ years $(n=34)$} \\
\hline Pretest TUG & $1,35(1,12 ; 1,57)$ & \multirow{2}{*}{0,0005} & \multirow{6}{*}{$\begin{array}{c}0,53 \\
(0,21 ; 0,85)\end{array}$} & \multirow{6}{*}{$\begin{array}{c}2,18 \\
(1,87 ; 2,48)\end{array}$} \\
\hline Post-test TUG & $1,91(1,63 ; 2,18)$ & & & \\
\hline Pretest 6MW & $1,38(1,15 ; 1,60)$ & \multirow{2}{*}{0,0003} & & \\
\hline Post-test 6MW & $0,82(0,50 ; 1,13)$ & & & \\
\hline Pretest STS & $1,41(1,16 ; 1,65)$ & \multirow{2}{*}{0,0037} & & \\
\hline Post-test STS & $1,85(1,48 ; 2,21)$ & & & \\
\hline \multicolumn{5}{|c|}{ Group 2: 65-69 years $(\mathrm{n}=31)$} \\
\hline Pretest TUG & $1,54(1,26 ; 1,82)$ & \multirow{2}{*}{0,2924} & \multirow{6}{*}{$\begin{array}{c}0,68 \\
(0,35 ; 1,02)\end{array}$} & \multirow{6}{*}{$\begin{array}{c}2,57 \\
(2,14 ; 2,97)^{*}\end{array}$} \\
\hline Post-test TUG & $1,58(1,22 ; 1,93)$ & & & \\
\hline Pretest 6MW & $1,45(1,15 ; 1,74)$ & \multirow{2}{*}{0,0009} & & \\
\hline Post-test 6MW & $0,96(0,63 ; 1,30)$ & & & \\
\hline Pretest STS & $1,29(1,01 ; 1,56)$ & \multirow{2}{*}{0,0002} & & \\
\hline Post-test STS & $1,93(1,60 ; 2,26)$ & & & \\
\hline \multicolumn{5}{|c|}{ Group 3: 70-74 years $(\mathrm{n}=18)$} \\
\hline Pretest TUG & $1,88(1,25 ; 2,52)$ & \multirow{2}{*}{0,5785} & \multirow{6}{*}{$\begin{array}{c}1,02 \\
(0,74 ; 1,41)^{\wedge}\end{array}$} & \multirow{6}{*}{$\begin{array}{c}4,26 \\
(3,83 ; 4,75)^{\wedge}\end{array}$} \\
\hline Post-test TUG & $1,94(1,21 ; 2,67)$ & & & \\
\hline Pretest 6MW & $2,16(1,74 ; 2,59)$ & \multirow{2}{*}{0,0008} & & \\
\hline Post-test 6MW & $1,11(0,54 ; 1,67)$ & & & \\
\hline Pretest STS & $2,05(1,65 ; 2,45)$ & \multirow{2}{*}{0,0204} & & \\
\hline Post-test STS & $2,61(1,99 ; 3,22)$ & & & \\
\hline
\end{tabular}

Note. Numeric pain rating scale (NPRS) - possible score for all tests $=0-10$ points; $\times$ - average value of pain for the last 24 hours; * - significant difference between G1 and G2, ^ ${ }^{\wedge}$ significant difference between G2 and G3; $\mathrm{p}<0.05$.

While studying the effect of the age on pain intensity during physical activity we received the following results. Statistical analysis showed a significant upward and downward change in indicators of knee joint pain before and after physical exertion (Table 4). 
Characteristic value of physical performance tests, $(\mathrm{M}, 95 \% \mathrm{Cl})$

Table 5

\begin{tabular}{|l|c|c|c|c|c|c|}
\hline \multicolumn{1}{|c|}{ Test } & $\mathrm{G} 1, \mathrm{n}=34$ & $\begin{array}{c}\mathrm{p} \\
\mathrm{G} 1-\mathrm{G} 2\end{array}$ & $\mathrm{G} 2, \mathrm{n}=31$ & $\begin{array}{c}\mathrm{p} \\
\mathrm{G} 2-\mathrm{G} 3\end{array}$ & $\mathrm{G} 3, \mathrm{n}=18$ & $\begin{array}{c}\mathrm{p} \\
\mathrm{G} 1-\mathrm{G} 3\end{array}$ \\
\hline TUG, $\mathrm{s}$ & $\begin{array}{c}6,83 \\
(6,63 ; 7,04)\end{array}$ & 0,229 & $\begin{array}{c}7,56 \\
(7,29 ; 7,82)\end{array}$ & 0,185 & $\begin{array}{c}8,73 \\
(8,26 ; 9,21)\end{array}$ & 0,015 \\
\hline 6MW, m & $\begin{array}{c}588,1 \\
(576,3 ; 599,9)\end{array}$ & 0,088 & $\begin{array}{c}548,6 \\
(539,5 ; 557,6)\end{array}$ & 0,244 & $\begin{array}{c}526,6 \\
(517,2 ; 536,1)\end{array}$ & 0,013 \\
\hline STS, s & $\begin{array}{c}1,71 \\
(1,69 ; 1,74)\end{array}$ & 0,155 & $\begin{array}{c}1,84 \\
(1,80 ; 1,87)\end{array}$ & 0,077 & $\begin{array}{c}2,01 \\
(1,94 ; 2,08)\end{array}$ & 0,002 \\
\hline
\end{tabular}

In group 1 (60-64 years), significant changes were recorded after each test $(p<0.01)$. However, if in TUG and STS tests indices of pain intensity demonstrated an increase $(p<0.01)$, after $6 \mathrm{MW}$ test pain decrease was recorded $(\mathrm{p}<0.01)$. In $\mathrm{G} 1$ and $\mathrm{G} 2$ significant changes were recorded in $6 \mathrm{MW}$ and STS tests $(\mathrm{p}<0.01)$, where the same tendency as in G1 was found - pain increase after STS test and pain decrease after $6 \mathrm{MW}$ test. However, it is worth noting that the TUG test did not change significantly the index of pain in $\mathrm{G} 2$ and $\mathrm{G} 3-\mathrm{p}=0.29$ and $\mathrm{p}=0.57$ respectively. However, in G1, its significant increase was recorded $(\mathrm{p}<0.01)$.

The data obtained show that the most expressive growth of pain in the knee joint was recorded after the STS test. The difference in expression of pain in TUG and 6MW test compared to the STS test can be explained by the differences in their procedures. During the TUG test, we allowed the participants to use hands in order to help themselves to stand up, while during the STS test, hands of the participants were strictly in the crossed position at the level of the chest. The angles of the knee joint when transiting from the sitting to standing position are the least beneficial. The compression load on the joint arising from standing and squatting movements occurs at angles less than 60 degrees [12], which makes it much more difficult to cope with the load on the joint, and the resulting compression causes pain. We believe that walking in this situation is not so much a factor affecting the occurrence of pain in the joint as a factor due to which a number of albeit short-term but positive changes occur the work of the respiratory and cardiovascular systems improves blood circulation and nutrient delivery to the bone and cartilage of the joint; the tone of muscles increases as well as the total range of motion in the joint [3].

Table 5 shows the indices of physical performance tests. The results clearly demonstrate that the "age" factor has a significant impact on the level of physical performance of the tested women. According to the indicators of the three studied groups, the dynamics of a decrease in the functional indicators of the subjects can be traced, and if there are no significant differences between adjacent groups (G1-G2 and G2-G3 $(p>0.05))$, then between G1-G3 groups statistically significant differences were recorded in relation to all functional tests - TUG $(\mathrm{p}=0.015)$, $6 \mathrm{MW}(\mathrm{p}=0.013)$, STS $(\mathrm{p}=0.002)$. Correlation analysis (Fig. 4A, B, C) also showed a pronounced dependence between women's physical performance and their age $(6 \mathrm{MW}, \mathrm{r}=-0.667$; TUG, $r=0.734$; STS, $r=0.781$ ).

Conclusion. Knee joint impairments are mainly represented by changes that appear at the beginning with minimal signs, but eventually progress to more complex pathological conditions. The main functional degenerative disorders include joint pain, limitation of its mobility, decreased trophism of soft periarticular tissues and their diseases.

Capability of a person to maintain optimal level of physical activity depends largely on the functional status of the locomotor system and its separate structural elements. The malfunction of the knee joint leads to a change in a balanced stereotype of movement thereby the position of a person becomes less stable. The increase of the number of movements in the knee joint aimed at its stabilization results in a compressive stress of the kneecap that becomes the reason of pain and decline of motions in the joint.

Estimation of the knee pain severity, decline of motions and level of physical performance in elderly women allow obtaining new data about the age dynamics of functional and degenerative disorders in the knee joint. The data obtained confirm that the age of elderly women is one of the main factors influencing their functional status. 


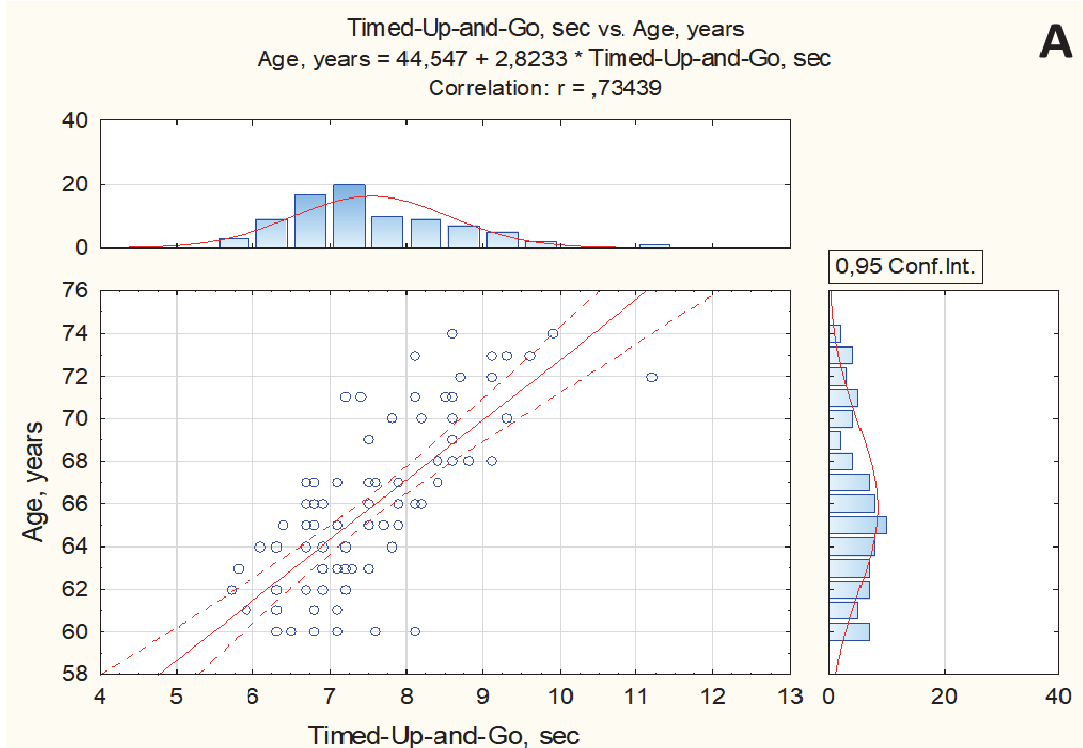

$6 \mathrm{MW}, \mathrm{m}$ vs. Age, years

Age, years $=105,08-, 0702 * 6 \mathrm{MW}, \mathrm{m}$ Correlation: $r=-, 6671$
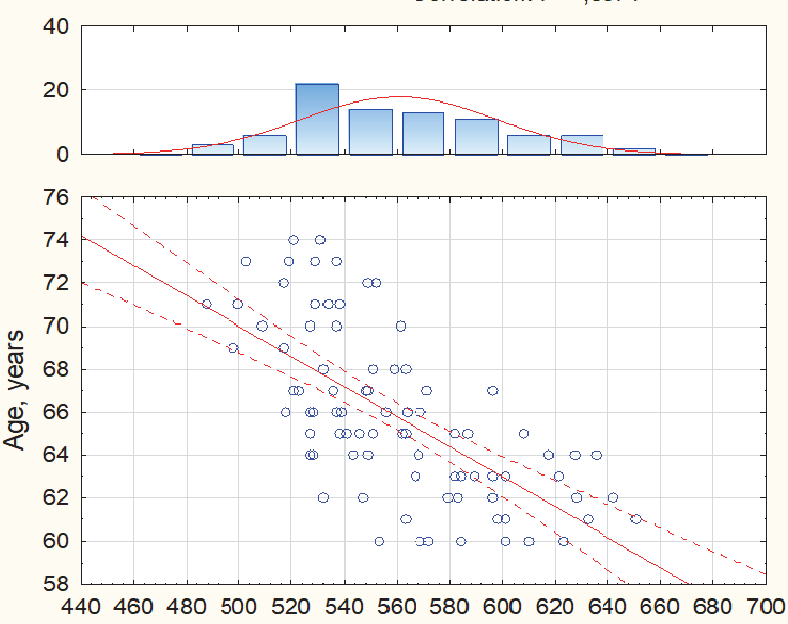

0,95 Conf.Int.

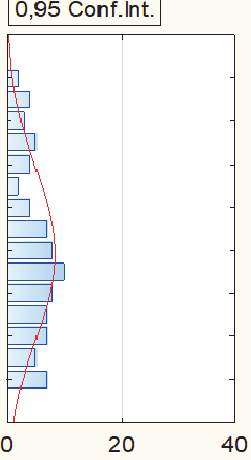
$6 \mathrm{MW}, \mathrm{m}$

Sit-to-stand, sec vs. Age, years

Age, years $=28,403+20,444$ * Sit-to-stand, sec Correlation: $r=, 78146$
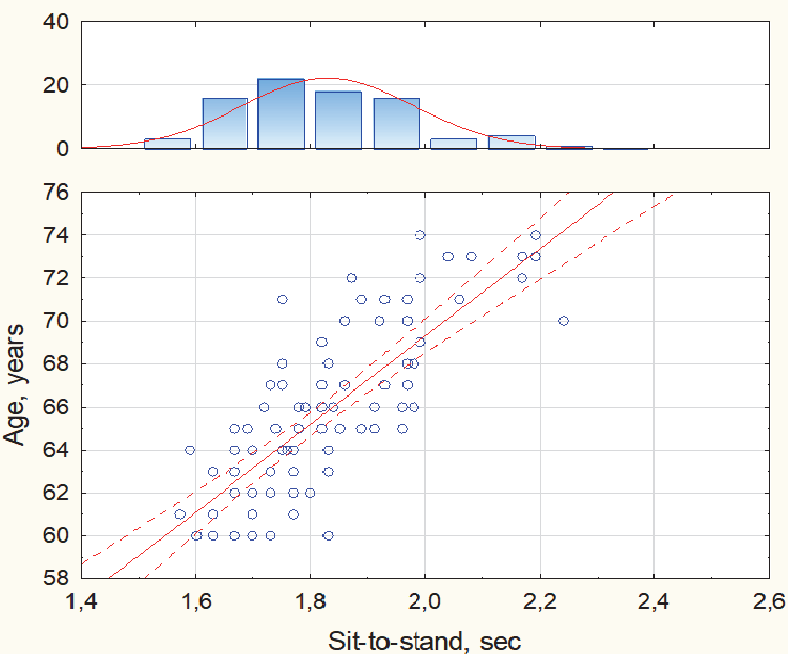

0,95 Conf.Int.

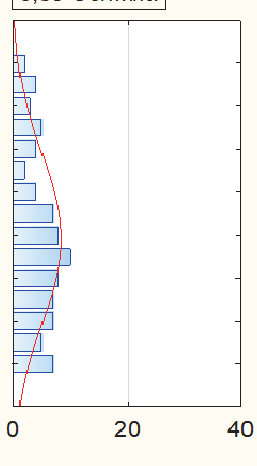

Fig. 4. Correlation between the age and physical performance tests $(\mathrm{M}, 95 \% \mathrm{Cl})$ 
It was established that the age is also one of the key factors influencing the progression of functional and degenerative disorders in the knee joint, which are not only accompanied by the increase of pain and stiffness but also have a great impact on functional capabilities in elderly women.

The functional assessment of the knee joint and level of physical performance will contribute to preparing and implementing the programs of physical activity enhancement and correction of the knee joint function in elderly women.

The article was made with the assistance of the Department for Education and Youth Policy in the Khanty-Mansi Autonomous Region - Yugra (project "Elaboration and implementation of new technology solutions for physical activity and health optimization, establishment of laws of body response on physical exertion of different modality in the conditions of KHMAO - Yugra").

\section{References}

1. Anni Rava, Anu Pihlak, Tatjana Kums, Priit Purge, Mati Pääsuke, Jaak Jürimäe. Associations of Distinct Levels of Physical Activity with Mobility in Independent Healthy Older Women. Experimental Gerontology, 2018, vol. 110, pp. 209-215. DOI: 10.1016/j.exger.2018.06.005

2. Borisov D.B., Kirov M.Yu. [Endoprothesis Replacement of Hip and Knee Joints. Epidemiological Aspects and Effect on Quality of Life]. Ekologiya cheloveka [Human Ecology Journal], 2013, no. 8, pp. 52-57. (in Russ.)

3. Broosters T., Gosselink R., Decramer M. Six-Minute Walking Distance in Healthy Elderly Subjects. Eur. Respir J, 1999, vol. 14, no. 2, pp. 270-274. DOI: 10.1034/j.1399-3003.1999.14b06.x

4. Corti M.C., Rigon C. Epidemiology of Osteoarthritis: Prevalence, Risk Factors and Functional Impact. Aging. Clin. Exp. Res., 2003, vol. 15 (5), pp. 359-363. DOI: 10.1007/BF03327356

5. Es'kov V.M., Loginov S.I., Mal'kov M.N., Snigirev A.S. [The Influence of Physical Exercises on Parameters of Functional Systems of Human Body in Conditions of Russian North. Synergetic Approach]. Teoriya i praktika fizicheskoy kul'tury [Theory and Practice of Physical Culture], 2009, no. 12, pp. 32-35. (in Russ.)

6. Jawahar R., Yang S., Eaton C.B., McAlindon T., Lapane K.L. Gender Specific Correlates of Complementary and Alternative Medicine Use for knee Osteoarthritis. J. Womens Health, 2012, vol. 21 (10), pp. 1091-1099. DOI: 10.1089/jwh.2011.3434

7. Kryvinia E.N., Mosunov D.F. [Aging and Objectives of Physical Culture in Old Age]. Adaptivnaya fizicheskaya kul'tura [Adapted Physical Education], 2015, vol. 61, no. 1, pp. 46-49. (in Russ.)

8. Loginov S.I. [Physical Activity of Elderly in the Yugorsky North]. Profilakticheskaya meditsina [Preventive Medicine], 2018, vol. 21, no. 2-2, p. 86. (in Russ.)

9. Morlock M., Schneider E., Bluhm A., Vollmer M., Bergmann G., Muller V., Honl M. Duration and Frequency of Everyday Activities in Total Hip Patients. J. Biomech, 2011, vol. 34, pp. 873-881. DOI: 10.1016/S0021-9290(01)00035-5

10. Nikolaev A.Yu., Loginov S.I. [The Influence of the Nordic Walking in Level of Physical Fitness at Older Women]. Materialy Vserossiyskoy s mezhdunarodnym uchastiyem nauchno-prakticheskoy konferentsii "Problemy i perspektivy fizicheskogo vospitaniya, sportivnoy trenirovki i adaptivnoy fizicheskoy kul'tury" [Proceedings of the All-Russian with International Participation Scientific-Practical Conference Problems and Prospects of Physical Education, Sports Training and Adaptive Physical Education], 2018, pp. 533-538. (in Russ.)

11. Pahor M., Ambrosius W.T., Guralnik J.M. Effect of Structured Physical Activity on Prevention of Major Mobility Disability in Older Adults: the LIFE Study Randomized Clinical Trial. JAMA, 2014, vol. 311 (23), pp. 2387-2396.

12. Radin E.L., Burr D.B., Caterson B. Mechanical Determinants of Osteoarthritis. Arthritis Rheum, 1991, vol. 21, suppl. 2, pp. 12-21. DOI: 10.1016/0049-0172(91)90036-Y

13. Shurgaya M.A. [The Disability of Citizen of Elderly Age in the Russian Federation]. Zdravookhraneniye Rossiyskoy Federatsii [Public Health of the Russian Federation], 2017, vol. 61, no. 6, pp. 292-299. (in Russ.) DOI: 10.18821/0044-197X-2017-61-6-292-299

14. Solodilov R.O. [Physiological and Biomechanical Analysis and Correction of the Functional Status of Knee Joint in Older Women with Gonarthrosis]. Zhurnal mediko-biologicheskikh issledovaniy [Journal of Medical and Biological Research], 2017, vol. 5, no. 2, pp. 74-81. (in Russ.) DOI: 10.17238/issn2542-1298.2017.5.2.74 


\title{
Восстановительная и спортивная медицина
}

15. Theiler R., Bischoff-Ferrari H.A., Good M., Bellamy N. Responsiveness of the Electronic Touch Screen WOMAC 3.1 OA Index in a Short-Term Clinical Trial with Rofecoxib. Osteoarthritis Cartilage, 2004, vol. 12 (11), pp. 912-916. DOI: 10.1016/j.joca.2004.08.006

16. United Nations, Department of Economic and Social Affairs, Population Division (2017). World Population Prospects: The 2017 Revision, Key Findings and Advance Tables. Working Paper No. $\mathrm{ESA} / \mathrm{P} / \mathrm{WP} / 248$.

Received 7 October 2019

Удк 796.012.45 + 616.7

DOI: $10.14529 / \mathrm{hsm} 190416$

\section{ВОЗРАСТНЫЕ ОСОБЕННОСТИ ФУНКЦИОНАЛЬНОГО СОСТОЯНИЯ КОЛЕННОГО СУСТАВА И УРОВНЯ ФИЗИЧЕСКОЙ РАБОТОСПОСОБНОСТИ ПОЖИЛЫХ ЖЕНЩИН}

\author{
Р.О. Солодилов \\ Сургутский государственный университет, г. Сургут, Россия
}

\begin{abstract}
Цель. Изучить возрастную динамику развития функциональных и дегенеративных нарушений коленного сустава и уровня физической работоспособности женщин пожилого возраста. Материалы и методы. В исследовании приняли участие три группы относительно здоровых женщин пожилого возраста (Г1 - 60-64 лет (n = 34), Г2 - 65-69 лет $(\mathrm{n}=31)$ и Г3 - 70-74 лет $(\mathrm{n}=18))$. С помощью индекса WOMAC оценили функциональное состояние коленного сустава (боль, ограничение подвижности, физическую функциональность). При помощи трех функциональных тестов провели оценку уровня физической работоспособности женщин. До и после проведения тестов с помощью цифровой рейтинговой шкалы боли проводили оценку боли в коленном суставе. Результаты. Показатели интенсивности боли и тугоподвижности в коленном суставе у пожилых женщин с возрастом достоверно увеличивались, в то время как уровень физической функциональности падал $(\mathrm{p}<0,01)$. Установлены корреляционные зависимости между показателями «возраст боль» $(\mathrm{r}=0,581)$, «возраст - тугоподвижность» $(\mathrm{r}=0,565)$ и «возраст - физическая функциональность» $(\mathrm{r}=0,666), \mathrm{p}<0,01$. Установлены достоверные изменения показателя боли в коленном суставе при выполнении физической нагрузки. Корреляционный анализ показал четко выраженную зависимость уровня физической работоспособности женщин от их возраста. Заключение. Полученные данные свидетельствуют, что возраст у пожилых женщин является одним из факторов, влияющих на прогрессирование функциональнодегенеративных нарушений в коленном суставе. Подтверждён факт того, что возраст оказывает непосредственное влияние на функциональные возможности пожилых женщин.

Ключевые слова: пожилье женщины, коленный сустав, физическая работоспособHocmb.
\end{abstract}

\section{Лumepamypa}

1. Associations of distinct levels of physical activity with mobility in independent healthy older women / Anni Rava, Anu Pihlak, Tatjana Kums, Priit Purge, Mati Pääsuke, Jaak Jürimäe // Experimental Gerontology. - 2018. - Vol. 110. - P. 209-215.

2. Борисов, Д.Б. Эндопротезирование тазобедренного и коленного суставов: эпидемиологические аспекты и влияние на качество жизни / Д.Б. Борисов, М.Ю. Киров // Экология человека. 2013. - № 8. - C. 52-57.

3. Six-minute walking distance in healthy elderly subjects / T. Broosters, R. Gosselink, M. Decramer // Eur. Respir J. - 1999. - Vol. 14. - № 2. - P. 270-274.

4. Epidemiology of osteoarthritis: prevalence, risk factors and functional impact / M.C. Corti, C. Rigon // Aging. Clin. Exp. Res. - 2003. - Vol. 15 (5). - P. 359-363. 
5. Еськов, В.М. Влияние физических упражнений на параметры функциональных систем организма человека в условиях Севера РФ: синергетический подход / В.М. Еськов, С.И. Логинов, М.Н. Мальков, А.С. Снигирев // Теория и практика физ. культурыл. - 2009. - № 12. - С. 32-35.

6. Gender specific correlates of complementary and alternative medicine use for knee osteoarthritis / R. Jawahar, S. Yang, C.B. Eaton et al. // J. Womens Health. - 2012. - Vol. 21 (10). - P. 1091-1099.

7. Крывиня, Е.Н. Старение и задачи физической культуры в пожсилом возрасте / Е.Н. Крывиня, Д.Ф. Мосунов // Адаптивная физ. культура. - 2015. - № 1 (61). - C. 46-49.

8. Логинов, С.И. Физическая активность пожилых на Югорском севере / С.И. Логинов // Профилактическая медииина. - 2018. - T. 21. - № 2-2. - C. 86.

9. Duration and frequency of everyday activities in total hip patients / M. Morlock, E. Schneider, A. Bluhm, M. Vollmer, G. Bergmann, V. Muller, M. Honl // J. Biomech. - 2011. - Vol. 34. - P. 873-881.

10. Влияние скандинавской ходьбы на уровень физической подготовленности женщин пожилого возраста / А.Ю. Николаев, С.И. Логинов // Материаль Всероссийской с международным участием научно-практической конференции «Проблемы и перспективы физического воспитания, спортивной тренировки и адаптивной физической культурыl», 2018. - C. 533-538.

11. Effect of structured physical activity on prevention of major mobility disability in older adults: the LIFE study randomized clinical trial / M. Pahor, J.M. Guralnik, W.T. Ambrosius // JAMA. - 2014. Vol. 311 (23). - P. 2387-2396.

12. Mechanical determinants of osteoarthritis / E.L. Radin, D.B. Burr, B. Caterson // Arthritis Rheum. - 1991. - Vol. 21. - Suppl. 2. - P. 12-21.

13. Шургая, М.А. Инвалидность граждан пожилого возраста в Российской Федераџии / М.A. Шургая // Здравоохранение Российской Федераџии. - 2017. - № 61 (6). - C. 292-299. DOI: 10.18821/0044-197X-2017-61-6-292-299

14. Солодилов, Р.О. Физиолого-биомеханический анализ и коррекиия функиионального состояния коленного сустава у женщин пожилого возраста с гонартрозом / Р. О. Солодилов // Журнал мед.-биол. исследований. - 2017. - T. 5, № 2. - C. 74-81. DOI: 10.17238/issn2542-1298.2017.5.2.74

15. Responsiveness of the electronic touch screen WOMAC $3.1 \mathrm{OA}$ Index in a short-term clinical trial with rofecoxib / R. Theiler, H.A. Bischoff-Ferrari, M. Good, N. Bellamy // Osteoarthritis Cartilage. 2004. - Vol. 12 (11). - P. 912-916.

16. United Nations, Department of Economic and Social Affairs, Population Division (2017). World Population Prospects: The 2017 Revision, Key Findings and Advance Tables. Working Paper No. $E S A / P / W P / 248$.

Солодилов Роман Олегович, кандидат биологических наук, младший научный сотрудник научно-образовательного цента Института гуманитарного образования и спорта, Сургутский государственный университет. 628400, г. Сургут, проспект Ленина, 1. E-mail: goodroman@mail.ru, ORCID: 0000-0002-4837-7427.

Поступила в редакцию 7 октября 2019 z.

\section{ОБРАЗЕЦ ЦИТИРОВАНИЯ}

Solodilov, R.O. Age Peculiarities of Knee Functionality and Physical Performance in Elderly Women / R.O. Solodilov // Человек. Спорт. Медицина. - 2019. T. 19, № 4. - C. 133-141. DOI: 10.14529/hsm190416

\section{FOR CITATION}

Solodilov R.O. Age Peculiarities of Knee Functionality and Physical Performance in Elderly Women. $\mathrm{Hu}$ man. Sport. Medicine, 2019, vol. 19, no. 4, pp. 133-141. DOI: $10.14529 / \mathrm{hsm} 190416$ 